\title{
CUSTOMER LOYALTY DURING COVID-19 OUTBREAK: THE MEDIATION OF CUSTOMER SATISFACTION IN ISLAMIC BANK
}

\author{
Asma' Munifatussa'idah \\ Islamic Economics, Airlangga University \\ e-mail: Asma.munifatussaidah-2019@feb.unair.ac.id \\ Khairul Saleh \\ State Polytechnic of Semarang \\ e-mail: khairul.saleh@polines.ac.id
}

\begin{abstract}
This Study aims to analyze the influence factors of customer loyalty, especially group of saving customers and single customer in Islamic commercial bank, using variable of price, relationship marketing, and customer value with customer satisfaction as an intervening variable. The studyis quantitative analytical methods and presents primary data collected through questionnaire with the purposive sampling technique. Total sample of 244 respondents from all local Islamic commercial bank in Indonesia during the COVID-19 outbreak period. The analysis model is Structural Equation Model (SEM), using confirmatory factor analysis and regression weight. Then, the result of this study showed that variable price, relationship marketing, and customer value partially have a positive and significant effect toward customer satisfaction. And customer satisfaction has a significant effect toward customer loyalty in Islamic commercial bank.
\end{abstract}

Keywords: Customer Satisfaction, Customer Loyalty, Islamic Bank, COVID-19

\begin{abstract}
Abstrak
Penelitian ini bertujuan untuk menganalisis faktor-faktor yang mempengaruhi loyalitas nasabah, khususnya pada nasabah simpanan/tabungan dan nasabah tunggal pada Bank Umum Syariah, dengan variabel harga, relationship marketing, dan nilai nasabah dengan kepuasan nasabah sebagai variabel intervening. Penelitian ini menggunakan metode analisis kuantitatif dengan data primer yang dikumpulkan melalui kuesioner, teknik yang digunakan adalah purposive sampling. Jumlah sampel pada penelitian ini 244 responden dari seluruh Bank Umum Syariah selama periode wabah COVID-19. Model analisis menggunakan Structural Equation Model (SEM), dengan teknik analisis confirmatory factor analysis dan regression weight. Hasil penelitian ini, menunjukkan bahwa harga, relationship marketing, dan nilai nasabah secara parsial berpengaruh
\end{abstract}


positif dan signifikan terhadap kepuasan nasabah. Dan kepuasan nasabah berpengaruh signifikan terhadap loyalitas nasabah pada Bank Umum Syariah.

Kata kunci: Kepuasan Nasabah, Loyalitas Nasabah, Bank Syariah, COVID-19

\section{INTRODUCTION}

The economic crisis during the COVID-19 outbreak greatly disrupted global economic activities, including business activities and Islamic finance (Zhang et al., 2020). It is known that the COVID-19 pandemic is expanding throughout the world, Since the World Health Organization (WHO) announced the first COVID-19 outbreak in Wuhan, Hubei province, China in December 2019, then President Joko Widodo announced the first case of COVID-19 in Indonesia in March 2, 2020 (Djalante et al., 2020). Global COVID-19 cases increased significantly based on statistical data from the Task Force for the Acceleration of Handling COVID-19 on Saturday, September 25, 2020, recording cumulatively Indonesia ranks 23 cases of the spread of COVID-19 globally from 216 countries exposed to corona virus and recorded as many 266,845 positive cases. Meanwhile, the number of recovered patients reached 196,196 cases and the death rate reached 10,308 people(Covid19.go.id, 2020).

The impact of the COVID-19 crisis on the Islamic economy and finance, especially the commercial financial sector and the halal industry, is relatively the same as the real and financial sectors. The COVID-19 pandemic has also caused a decline in the performance of the Islamic financial services sector (bi.go.id, 2019). One of them, Islamic banks must have a family of new strategies in other to the business continues, and immediately adapts to corona pandemic conditions. This includes providing banking services with a complete health protocol. So that it will maintain the level of good performance and hope that the bank's intermediary function will run as well, and be able to drive national economic growth in new normal era. In December 2019 to April 2020, Bank Indonesia and the Financial Services Authority (OJK) have issued policies to maintain the stability of the financial services sector amid the COVID-19 outbreak in Indonesia (ojk.go.id, May 2020). This was done, aimed at maintaining the stability of banking performance in Indonesia, including Islamic bank.

The COVID-19 outbreak forces individuals, groups, institutions, and also countries to change their lifestyle and behavior in their daily lives, is called a new normal. Thus, the banking industry needs to change its service strategy so that customer satisfaction levels do not decrease and have an impact on their loyalty. Customer loyalty will be created by the satisfaction felt by customers. Customers who are satisfied with the performance of the company will become loyal customers of the company. Customers are said to be satisfied when the benefits they receive are proportional to the costs (sacrifices) that have been incurred (Kamath et al., 2019). Customer satisfaction concerns what is expressed by customers regarding their perceptions and expectations of the banking services obtained. Customer satisfaction is not enough, because satisfied or dissatisfied is just one form of emotion (Tjiptono, 2007). Meanwhile, loyalty shows a feeling of satisfaction and a desire to have a long-term relationship (Kartika et al., 2019). So, in the new normal era, it is interesting to do research on customer loyalty at Islamic commercial banks during the COVID-19 outbreak.

Islamic banking in maintaining customer satisfaction and building customer loyalty can be influenced by pricing (Rama, 2020), however price tends not to have an effect because price is not a problem for the customer to get what he wants (Farida et al., 
2016). Relationship marketing variable influence customer satisfaction (Majuarsa et al., 2013), but at a different level of significance. Customer value also influence customer satisfaction (Zaini et al., 2017) and then the variable customer satisfaction as a mediation between the three factors with customer loyalty will affect the level of customer loyalty (Haron et al., 2020; Kamath et al., 2019). From several previous research with the variables used, this study is the difference in customer conditions at the time of the COVID-19 outbreak with the application of new normal to Islamic banking services. Therefore, this study will analyze the effect of price, relationship marketing, and customer value toward customer loyalty in Islamic Commercial Banks, with customer satisfaction as an intervening variable.

\section{LITERATURE REVIEW Customer Satisfaction}

Customer satisfaction describes the level of a person's feelings in stating the results of the comparison of the performance of service products received and expected. Customer satisfaction, how far is the perception of the performance of a product in accordance with the expectations of a buyer (Kotler \& Armstrong, 2012). Thus customer satisfaction can be formed when the performance of the service products consumed has matched or even exceeds the expectations desired by the customer so that it is able to provide a sense of pleasure and a level of comfort after consuming the service product (Sefesiyani et al., 2015).

Then, customer decision can provide several benefits, including harmonious relationship between the company and customers, providing a rich basis for repeat purchases and creating customer loyalty, and forming a word of mouth recommendation that is beneficial for the company(Alnaser et al., 2017).

One of the things needed to achieve customer loyalty is customer satisfaction (Dandis \& Wright, 2020; Sheng \& Liu, 2010). Customer satisfaction as a response after purchase that occurs as a result of comparing pre-purchase expectations and perceived performance (Tjiptono, 2007). The level of expectation then becomes the standard for the service product being assessed. This means that after the service product is used, the results are compared to expectations, if the perceived performance matches or even exceeds customer expectations, the customer will feel satisfied. If not, then the customer is not satisfied. In the business world, customer satisfaction is seen as a dimension of market performance. A customer, if he is satisfied with the value provided by a product or service, is very likely to be a customer of an Islamic bank for a long time (Kurniawan \& Shihab, 2015).

\section{Customer Loyalty}

Loyalty relates to what customers do after interacting in a banking service process (Kartika et al., 2019). Customer loyalty is a deeply held commitment to buy or support a preferred product or service in the future even though the situation and marketing efforts have the potential to cause customers to switch (Tjiptono, 2007). Loyalty has three categories of approaches, namely the behavioral approach, the attitude approach, and the integrated approach. The behavioral approach focuses on customer behavior after purchase and measures loyalty based on the level of purchase or frequency and likelihood of repurchasing (Lupiyoadi, 2016).

The attitude approach concludes loyalty from aspects of psychological involvement and favoritism to certain services. Meanwhile, the integrated approach 
combines these two variables. So that customer loyalty can be understood as a combination of customer pleasure and repurchasing behavior (Lupiyoadi, 2016). The characteristics of customers loyalty include: 1) Making regular repeat purchases; 2) Purchasing additional products and services from the company; 3) Demonstrates immunity to pull from competitors; and 4) Referring to others.

\section{Price}

Price plays an important role in the marketing mix process, because the various benefits possessed by a service product must be compared with the various costs (sacrifices) incurred in consuming these services (Hosen et al., 2019). Price is one that affects customer satisfaction, where an attractive price for customers will satisfy customers in making transactions (Lupiyoadi, 2016). Price as the amount charged for a product or service. Pricing strategies are related to revenue and influence marketing demand and channels (Kotler \& Armstrong, 2012). In various situations, customers are faced with various considerations regarding what customers will get at a certain cost if they consume these services. These costs can be in the form of prices that must be paid for services, time that must be sacrificed, physical effort (energy that must be expended), and sacrifices related to the senses (Hosen et al., 2019).

\section{Relationship Marketing}

Relationship marketing is a process of creating, maintaining and enhancing strong and high value relationships with customers and other interested parties (Kotler \& Armstrong, 2012). Relationship marketing is the introduction of each customer in more detail by creating two-way communication by managing a profitable relationship between customers and Islamic banks, thus making Islamic banks always have a longterm frame of mind (Chan, 2003).

Relationship marketing is a form of relationship created by Islamic banks with customers with the aim of maintaining good relations between Islamic banks and customers. Relationship marketing strongly emphasizes that Islamic banks must be able to know and understand customer needs and wants, realize customer expectations and be able to treat customers better. This will make customers feel cared for and appreciated, which in turn creates long-term customer loyalty to Islamic banks (Pranomo \& Warso, 2016). So, relationship marketing is an effort to introduce each customer more closely, create two-way communication with consumers, and manage mutually beneficial relationships between customers and companies (Lupiyoadi, 2016).

\section{Customer Value}

Customer value is the customer's perception of the balance between the benefits received and the sacrifices given to get these benefits (Hasan, 2010). Then customer value is the difference between the value obtained by the customer by owning and using a product, and the costs incurred to obtain the product(Kotler \& Armstrong, 2012). Customer value as an overall customer assessment of product benefits based on what they receive and what they provide (Tjiptono, 2007).

\section{METHOD}

Research method of this study is quantitative research. This study not only to artificially describe why and how customer loyalty is increased, or why and how customer satisfaction is built as an intermediary for price, relationship marketing, and 
customer value, but also wants to obtain empirical evidence that can be ascertained by statistical calculations. This study uses primary data, which is obtained directly from distributing questionnaires both online and offline (meeting directly with respondents). The spread is specifically for savings customers and single customers (with one account ownership) at Islamic commercial banks. The type of data of this research is cross section data with an interval scale of 1-10, with the information "strongly disagree" to "strongly agree" as a measure for each indicator.

\section{Sample}

Determination of the study sample size using the method of Hair, et al (2010) (Sulistiyorini, 2018), researchers distributed 244 questionnaires to customers of Islamic Commercial Banks. During the time span of June-August 2020. The sampling technique used purposive sampling by selecting respondents based on certain criteria, which are considered to have a relationship with previously known population characteristics. The sample criteria are savings customers and single customers, who have a minimum account for one year, because they are considered experienced in price, relationship marketing, and customer value in building customer satisfaction to increase customer loyalty.

\section{Operational definition}

Price $\left(\mathrm{X}_{1}\right)$ is the amount of costs that must be incurred to obtain a certain product or service. Price variable indicators are measured by: no administrative costs $\left(\mathrm{X}_{1.1}\right)$, no cash withdrawal costs through ATM Link $\left(\mathrm{X}_{1.2}\right)$, the balance of savings products is smaller than other banks $\left(\mathrm{X}_{1.3}\right)$, and the product profit sharing ratio savings are higher than other banks $\left(\mathrm{X}_{1.4}\right)$ (Kurniawan et al., 2016; Majuarsa et al., 2013).

Relationship marketing $\left(\mathrm{X}_{2}\right)$ is an effort to get to know each customer more closely, create two-way communication with consumers, and manage mutually beneficial relationships between customers and companies. Relationship marketing variable indicators are measured by: efforts to care for the bank on transaction security $\left(\mathrm{X}_{2.1}\right)$, bank efforts to always adapt products to customer needs $\left(\mathrm{X}_{2.2}\right)$, bank efforts to always provide the latest product information to customers $\left(\mathrm{X}_{2.3}\right)$, and handling of customer complaints $\left(\mathrm{X}_{2.4}\right)$ (Putrayuda \& Jahrizal, 2020; Sefesiyani et al., 2015).

Customer value $\left(\mathrm{X}_{3}\right)$ is a customer's overall assessment of the benefits of a product based on what they receive and what they provide. Indicators of customer value variables are measured by: conformity of product features with customer perceptions $\left(\mathrm{X}_{3.1}\right)$, conformity of bank services with customer perceptions $\left(\mathrm{X}_{3.2}\right)$, conformity of bank employee attitudes with customer perceptions $\left(\mathrm{X}_{3.3}\right)$, and suitability of cost of sacrifice with services banking obtained $\left(\mathrm{X}_{3.4}\right)$ (Astono, 2017).

Customer satisfaction $\left(\mathrm{Y}_{1}\right)$ is the level of feeling where a person states the results of the comparison of the performance of the received and expected service products. Indicators of customer satisfaction variables are measured by: satisfaction with operations in accordance with Islamic law $\left(\mathrm{Y}_{1.1}\right)$, feeling good about the service received $\left(\mathrm{Y}_{1.2}\right)$, satisfaction with the suitability of bank services with customer expectations $\left(\mathrm{Y}_{1.3}\right)$, the right choice because according to Islamic principles $\left(\mathrm{Y}_{1.4}\right)$ (Azizah, 2012; Sheng \& Liu, 2010).

Customer loyalty $\left(\mathrm{Y}_{2}\right)$ is a deeply held commitment to buy or re-support a preferred product or service in the future even though situation and marketing influences have the potential to cause customers to switch. Indicators of customer 
loyalty variables are measured by: commitment to always use bank products $\left(\mathrm{Y}_{2.1}\right)$, commitment to buy more than one type of bank product $\left(\mathrm{Y}_{2.2}\right)$, commitment to recommend bank products $\left(\mathrm{Y}_{2.3}\right)$, and commitment to survive $\left(\mathrm{Y}_{2.4}\right)$ (Sefesiyani et al., 2015; Suhartanto et al., 2020).

Based on variable indicators of price, relationship marketing, customer value to customer loyalty, with customer satisfaction as an intervening variable. Arranged in a path diagram (Figure 1) as follows:

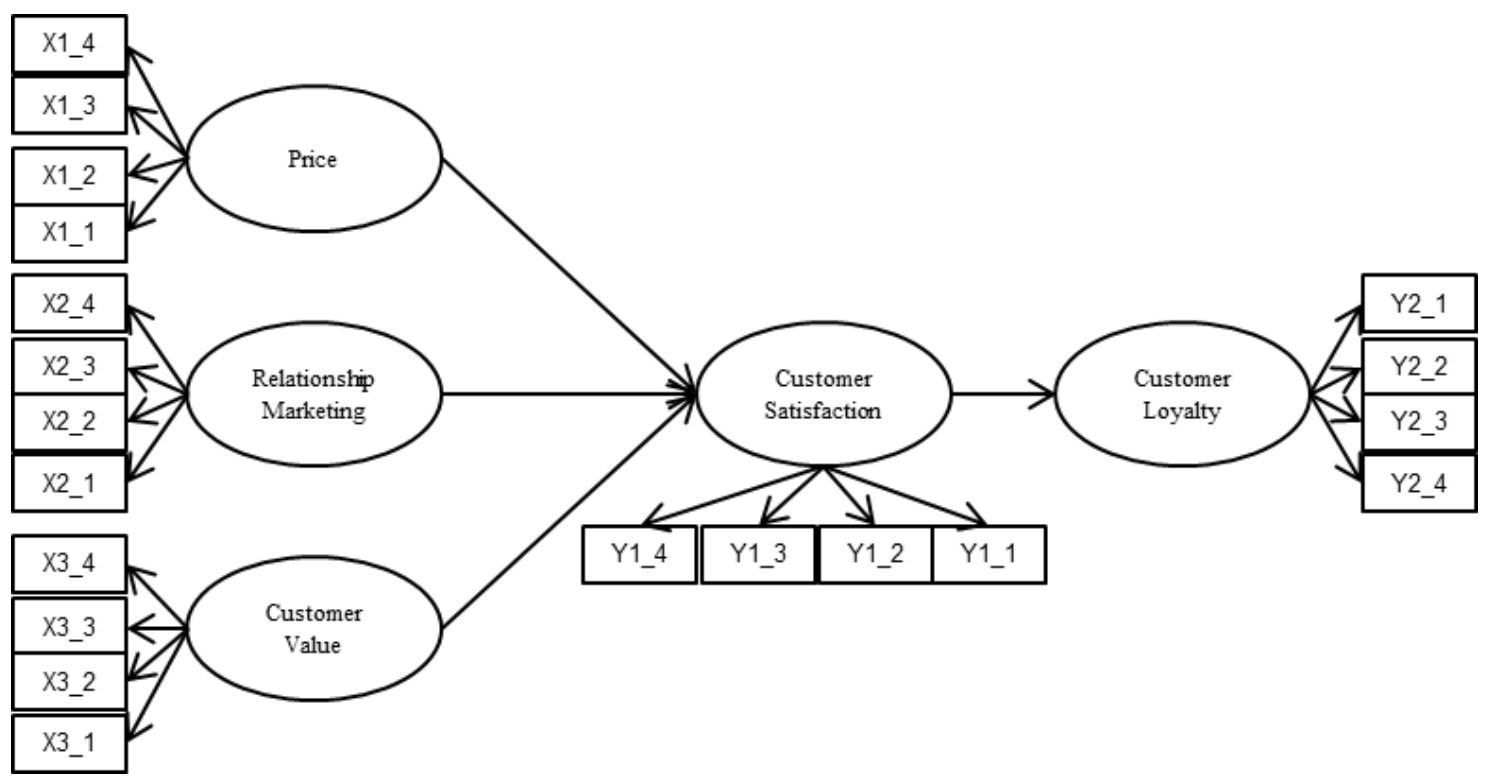

Figure 1. Research Model

Source: primary data, processed 2020

\section{Analysis Technique}

The data analysis method used in this research is Structural Equation Modeling (SEM), confirmatory test, and regression weights test, which are operated through the AMOS 22.0 program. The use of SEM in this research is because SEM provides a conceptual model to test the theory. The SEM test can determine the suitability between the theory being built and reality which can be seen from the data obtained in the field (Sulistiyorini, 2018).

\section{RESULT AND DISCUSSION}

The model in the path diagram (Figure 1) is converted into a structural equation as follows;
Endogenous Variables
$=$ Exogenous Variable + Endogenous Variable + Error
Customer Satisfaction
$=0.320$ Price +0.220 Relationship Marketing +0.150
Customer Value $+0.49 \zeta 1$
Customer Loyalty
$=0,60$ Customer Satisfaction $+\zeta 2$

\section{Confirmatory Factor Analysis}

\section{Exogenous and Endogenous Confirmatory Tests}

The analysis of exogenous construct confirmatory factors aims to test the unidimensionality of the dimensions forming each of price, relationship marketing, and 
customer value. Meanwhile, analysis of endogenous construct confirmatory factors aims to test the unidimensionality of the dimensions forming each of customer satisfaction and customer loyalty.

Table 1. Results of Exogenous and Endogenous Constructive Confirmatory Factor Analysis

\begin{tabular}{|c|c|c|c|c|}
\hline Variable & Criteria & Cut off Value & Result & Model Evaluation \\
\hline Eksogen: & & & & \\
\hline $\begin{array}{l}\text { Price }\left(X_{1}\right) \\
\text { Relationship Marketing }\end{array}$ & Chi-square & 68,669 & 55,420 & Good \\
\hline $\begin{array}{l}\left(\mathrm{X}_{2}\right) \\
\text { Customer Value }\left(\mathrm{X}_{3}\right) \\
\text { Endogen : }\end{array}$ & Probability & $>0,05$ & 0,312 & Good \\
\hline $\begin{array}{l}\text { Customer Satisfaction } \\
\left(\mathrm{Y}_{1}\right)\end{array}$ & Chi-square & 30,144 & 45,502 & Marginal \\
\hline Customer Loyalty $\left(\mathrm{Y}_{2}\right)$ & Probability & $>0,05$ & 0,001 & Marginal \\
\hline
\end{tabular}

Source: Primary data, processed by author 2020

Based on Table 1, can be concluded that price, relationship marketing, and customer value deserve to be tested at the full model stage, because the results of the absolute, incremental, and parsimonius fit tests are still within the tolerable limits of feasibility. The results of this analysis can be said to meet the required standard criteria. The results of data analysis show that the observed variables (indicators) of customer satisfaction and customer loyalty are valid because they have a coefficient (loading factor) above 0.5 which indicates that there is a match between the indicators. Then, none of the observed variables (indicators) were omitted because each indicator that formed customer satisfaction and customer loyalty showed results that met the criteria, namely the value of Critical Ratio (CR) > 1.96 with Probability (P) less than 0.05 . These results, said that the indicators of customer satisfaction and customer loyalty have shown unidimensionality or a series that cannot be separated.

Based on Table 1, can be concluded that customer satisfaction and customer loyalty deserve to be tested at the full model stage, because the results of the absolute, incremental, and parsimonius fit tests are still within the tolerable limits of feasibility. The results of this analysis can be said to meet the required standard criteria. The results of data analysis show that the observed variables (indicators) of customer satisfaction and customer loyalty are valid because they have a coefficient value or loading factor above 0.5 which indicates that there is a match between the indicators. Then, none of the observed variables (indicators) were omitted because each indicator or dimension that formed customer satisfaction and customer loyalty showed results that met the criteria, namely the value of Critical Ratio (CR) $>1.96$ with Probability (P) less than 0.05. These results, said that the indicators of customer satisfaction and customer loyalty have shown unidimensionality or a series that cannot be separated.

\section{Regression Weights Test}

In this study, there are four hypotheses proposed, namely and the complete discussion can be explained based on the results of the full model construct regression weights test in Table 2 . 
Table 2 Full Model Regression Weights Test Results

\begin{tabular}{lrllr}
\hline & & & C.R. & P \\
\hline Customer_Satisfaction & $<---$ & Price & 4,115 & $* * *$ \\
Customer_Satisfaction & $<---$ & Relationship_Marketing & 3,025 & 0,002 \\
Customer_Satisfaction & $<---$ & Customer_Value & 2,473 & 0,013 \\
Customer_Loyalty & $<---$ & Customer_Satisfaction & 4,982 & $* * *$ \\
\hline
\end{tabular}

Source: Primary data, processed by author 2020

\section{The Effect of Price on Customer Satisfaction}

Based on the results of the full model Regression Weights test (Table 2), the Critical Ratio (CR) value is 4.115 with a Profitability (P) of 0.000 . The two values obtained meet the requirements for acceptance of the hypothesis, namely Critical Ratio (CR) above 1.96 and Probability below 0.05. Thus, price has a significant effect on customer satisfaction.

The form price of the amount of money charged for a product or service. The customer will be satisfied if the price offered by the product is in accordance with the quality of the product he received. A product can be said to be of high quality if the product is able to provide maximum benefits and minimum sacrifice (Kotler \& Armstrong, 2012). Prices that are in accordance with the benefits received by customers are a determining factor for customer satisfaction. Therefore, it is hoped that the management of Sharia Banks can improve their competitive pricing strategy through monthly administration fees, savings deposits, profit sharing ratios for savings products, and cash withdrawal fees via ATM Link. If this is done properly by the management of the Sharia Bank, the price for savings product will be attractive to customers. Thus, customer satisfaction of Islamic Bank savings increases.

The results of this study are in accordance with (Lupiyoadi, 2016) which states that pricing is related to revenue and contributes to marketing demand and channels. This corresponds to (Majuarsa et al., 2013), price is one that affects customer satisfaction, where an attractive price for customers will satisfy customers in making transactions. These findings support the research results (Hosen et al., 2019; Kurniawan et al., 2016) which shows that price has a positive and significant effect on customer satisfaction. This finding contradicts the results of the study (Farida et al., 2016) which indicates that price does not have a significant effect on satisfaction.

\section{The Effect of Relationship Marketing on Customer Satisfaction}

Based on the results of the full model Regression Weights test (Table 2), the Critical Ratio (CR) value is 3.025 with a Profitability $(\mathrm{P})$ of 0.002 . The two values obtained meet the requirements for acceptance of the hypothesis, namely Critical Ratio (CR) above 1.96 and Probability below 0.05 . Thus, relationship marketing has a significant effect on customer satisfaction.

Relationship marketing strongly emphasizes that the company must be able to know and understand customer needs and wants, realize customer expectations and be able to treat customers better. This will make customers feel cared for and appreciated, which in turn creates long-term customer loyalty to the company (Kotler \& Armstrong, 2012). The management of Islamic Banks is expected to increase the efforts of banks to always provide the latest product information to customers, handling customer complaints, bank concerns on customer transaction security, and bank products that adapt to customer needs. If this is done properly by the management of Islamic banks, 
then relationship marketing can increase. Thus, customer satisfaction of Islamic Bank savings increases.

The results of this study are in accordance with (Lupiyoadi, 2016) which states that relationship marketing is an effort to introduce each customer more closely, create two-way communication with consumers, and manage mutually beneficial relationships between customers and companies. Relationship marketing allows companies to retain customers through perceived satisfaction. This corresponds to (Chan, 2003) which states that through relationship marketing, Islamic banks can provide added value to customers, create customer satisfaction by understanding their desires and can make efforts to get to know better customers. These findings support the research results (De Bruin et al., 2020; Putrayuda \& Jahrizal, 2020; Putri \& Abdillah, 2014) which shows that relationship marketing has a significant effect on customer satisfaction.

\section{The Effect of Customer Value on Customer Satisfaction}

Based on the results of the full model Regression Weights test (Table 2), the Critical Ratio (CR) value is 2.473 with a Profitability (P) of 0.013 . The two values obtained meet the requirements for acceptance of the hypothesis, namely Critical Ratio (CR) above 1.96 and Probability below 0.05 . Thus, it is stated that customer value has a significant effect on customer satisfaction.

Customer value will be formed when the benefits that the customer gets are greater than the sacrifices that have been given. The better the value or benefits provided by the company to its customers, the customers will be satisfied (Astono, 2017). Therefore, the management of Islamic banks is expected to increase customer value by creating conformity to product features, bank services, and attitudes of bank employees with customer perceptions, as well as the compatibility of sacrifices with the banking services obtained. If this is done well by the management of Islamic banks, the value for customers will be even greater. Thus, customer satisfaction of Islamic Bank savings increases.

The results of this study are in accordance with (Hasan, 2010) which states customer value is seen as a reflection of the quality, benefits and sacrifices given to getting a product or service. A banking product or service is said to have a high value in the eyes of customers if it is able to provide the minimum possible quality, benefits and sacrifices. The better the value for customers provided by the Islamic Bank, the more satisfied the customer is with the product.These findings support the research results (Astono, 2017; Tjokro et al., 2018; Zaini et al., 2017) which shows that customer value has a positive and significant effect on customer satisfaction.

\section{The Effect of Customer Satisfaction on Customer Loyalty}

Based on the results of the full model Regression Weights test (Table 2), the Critical Ratio (CR) value is 4.982 with a Profitability $(\mathrm{P})$ of 0.000 . The two values obtained meet the requirements for acceptance of the hypothesis, namely Critical Ratio (CR) above 1.96 and Probability below 0.05. Thus, it can be stated that customer satisfaction has a significant effect on customer loyalty.

Increased customer satisfaction has the potential to lead to long-term and shortterm sales growth and market share as a result of repeat purchases (Kotler \& Armstrong, 2012). Customer satisfaction is the response given by the customer for the fulfillment of a need, so as to get a feeling of pleasure or comfort. Thus, the assessment of the advantages of the service itself can provide a level of comfort associated with meeting a 
need, including meeting needs that are appropriate or exceed expectations (Kotler \& Keller, 2009). Therefore, the management of Sharia Banks is expected to increase customer satisfaction through conformity of bank services to customer expectations, provide customer satisfaction with the services received, conformity of bank operations with Islamic law, and make customers believe that Islamic Bank is the right choice in partnering because it is appropriate. with Islamic principles. If this is done properly by the management of Islamic banks, customer satisfaction can increase savings. Thus, customer loyalty for Islamic Bank savings increases.

The results of this study are in accordance with (Kotler \& Keller, 2009) which states that customer satisfaction is the level of feeling where someone states the results of the comparison of the performance of service products received and expected. The higher the level of satisfaction, the higher the customer loyalty.These findings support the research results (Aisyah, 2018; Gopi, 2020; Putrayuda \& Jahrizal, 2020; Tjokro et al., 2018) which states that customer satisfaction has a positive and significant effect on customer loyalty.

\section{CONCLUSION}

Based on the results of research and discussion can be concluded that price, relationship marketing, and customer value are all factors that affect customer satisfaction. Customer satisfaction as an intervening variable can be a variable that increases customer loyalty to Islamic commercial banks during the COVID-19 outbreak period. Research limitations on the sample of customers of Islamic bank savings do not include financing customers. The managerial implication in this research is that pricing strategies are important to maintain and increase customer satisfaction. Islamic commercial banks are expected to pay attention to the value of satisfaction through the suitability of administrative costs with product quality, the suitability of a minimum balance deposited with product benefits, the suitability of the cash tark fee at the ATM with bank services, and the cost match with the profit sharing ratio received by the customer. Then, in relationship marketing to maintain and improve relationships and communication with customers through the bank's efforts to always provide the latest product information to customers, efforts to handle customer complaints, efforts to care for the bank with transaction security, and the bank's efforts to always adapt products to customer needs. Customer value is to understand customers by providing product features that match or even exceed customer expectations, bank employee attitudes that match or even exceed customer expectations, sacrifice fees that are in accordance with the banking services obtained, and bank services that match or even exceed customer expectations. And create satisfaction with the suitability of bank services with customer expectations, feeling happy with the services received, the right choice according to Islamic principles, and satisfaction with the suitability of bank operations with Islamic law. So that customers feel right to have chosen Islamic Bank as a partner.

\section{REFERENCES}

Aisyah, M. (2018). Islamic Bank Service Quality. Al-Iqtishad: Jurnal Ilmu Ekonomi Syariah (Journal of Islamic Economics), 10(2), 367-388.

Alnaser, F. M., Abd Ghani, M., Rahi, S., Mansour, M., \& Abed, H. (2017). Determinants of Customer Loyalty: The Role of Service Quality, Customer Satisfaction and Bank Image of Islamic Banks in Palestine. International Journal of Economics \& Management Sciences, 06(05). https://doi.org/10.4172/2162- 
6359.1000461

Astono, A. (2017). Pengaruh Kualitas Layanan, Nilai Nasabah Dan Kepuasan Nasabah Terhadap Loyalitas Nasabah Tabungan. Seminar Nasional Dan Call for Paper 2017.

Azizah, H. (2012). Pengaruh Kualitas Layanan, Citra Dan Kepuasan Terhadap Loyalitas Nasabah. Management Analysis Journal, 1(2).

Chan. (2003). Relationship Marketing, Inovasi Pemasaran yang Membuat Pelanggan Bertekuk Lutut. Gramedia Pustaka Utama.

Dandis, A. O., \& Wright, L. T. (2020). The effects of CARTER model on attitudinal loyalty in Islamic banks. International Journal of Quality and Service Sciences, 12(2), 149-171. https://doi.org/10.1108/IJQSS-03-2019-0050

De Bruin, L., Roberts-Lombard, M., \& De Meyer-Heydenrych, C. (2020). Internal marketing, service quality and perceived customer satisfaction: An Islamic banking perspective. Journal of Islamic Marketing. https://doi.org/10.1108/JIMA-09-20190185

Djalante, R., Lassa, J., Setiamarga, D., Sudjatma, A., Indrawan, M., Haryanto, B., Mahfud, C., Sinapoy, M. S., Djalante, S., Rafliana, I., Gunawan, L. A., Surtiari, G. A. K., \& Warsilah, H. (2020). Review and analysis of current responses to COVID-19 in Indonesia: Period of January to March 2020. Progress in Disaster Science, 6, 100091. https://doi.org/10.1016/j.pdisas.2020.100091

Farida, I., Tarmizi, A., \& Yogi. (2016). Analisis Pengaruh Bauran Pemasaran 7p Terhadap Kepuasan Pelanggan. Jurnal Riset Manajemen Dan Bisnis, 1(1), 31-40.

Gopi, B. (2020). The influence of food trucks' service quality on customer satisfaction and its impact toward customer loyalty. British Food Journal. https://doi.org/10.1108/BFJ-02-2020-0110

Haron, R., Subar, N. A., \& Ibrahim, K. (2020). Service quality of Islamic banks: satisfaction, loyalty and the mediating role of trust. Islamic Economic Studies. https://doi.org/10.1108/IES-12-2019-0041

Hasan, A. (2010). Marketing Bank Syariah. Cetakan I. Ghalian Indonesia.

Hosen, M. N., Lathifah, F., \& Jie, F. (2019). Perception and expectation of customers in Islamic bank perspective. Journal of Islamic Marketing. https://doi.org/10.1108/JIMA-12-2018-0235

Kamath, P. R., Pai, Y. P., \& Prabhu, N. K. P. (2019). Building customer loyalty in retail banking: a serial-mediation approach. International Journal of Bank Marketing, 38(2), 456-484. https://doi.org/10.1108/IJBM-01-2019-0034

Kartika, T., Firdaus, A., \& Najib, M. (2019). Contrasting the drivers of customer loyalty; financing and depositor customer, single and dual customer, in Indonesian Islamic bank. Journal of Islamic Marketing, 11(4), 933-959. https://doi.org/10.1108/JIMA-04-2017-0040

Kotler, P., \& Amstrong, G. (2012). Prinsiples of Marketing. Global Edition.

Kotler, P., \& Keller, K. L. (2009). Manajemen pemasaran. Terjemahan Bob Sabran. Erlangga.

Kurniawan, H., Satria, A., \& Suprayitno, G. (2016). Perancangan Strategi Bauran Pemasaran untuk Meningkatkan Kepuasan dan Loyalitas Nasabah. Jurnal Aplikasi Bisnis Dan Manajemen, 2(1).

Kurniawan, \& Shihab. (2015). Pengaruh Nilai Nasabah, Kualitas Pelayanan, dan Kualitas Hubungan terhadap Kepuasan Nasabah serta Implikasinya terhadap Loyalitas Nasabah Bank Syariah Mandiri. Jurnal Manajemen Dan Bisnis 
Sriwijaya, 13(2).

Lupiyoadi, R. (2016). Manajemen Pemasaran Jasa. Salemba Empat.

Majuarsa, I. W., Astuti, W., \& Chandrarin, G. (2013). Analisis Kualitas Layanan dalam Memediasi Pengaruh Harga, Produk, Pemasaran Relasional, dan MCSQ terhadap Kepuasan Pelanggan. Jurnal Akuntansi, 53(9), 1689-1699. https://doi.org/10.1017/CBO9781107415324.004

Pranomo, H., \& Warso. (2016). Pengaruh Relationship Marketing terhadap Loyalitas Pelanggan dengan Kepuasan Pelanggan Sebagai Variabel Intervening. Journal of Management, 2(2).

Putrayuda, T. R., \& Jahrizal. (2020). Pengaruh relationship marketing , kualitas produk terhadap kepuasan dan loyalitas nasabah penggunaan kartu kredit pada pt. bank riau kepri (studi pada cabang utama dan cabang pekanbaru. Jurnal Tepak Manajemen Bisnis, XII(1), 203-219.

Putri, U. P. S., \& Abdillah, Y. (2014). Pengaruh Relationship Marketing Terhadap Kepuasan dan Loyalitas Nasabah. Jurnal Administrasi Bisnis (JAB), 15(2).

Rama, A. (2020). Strategic pricing by Islamic banks and the impact on customer satisfaction and behavioral intention. Journal of Islamic Accounting and Business Research. https://doi.org/10.1108/JIABR-04-2019-0078

Sefesiyani, D.H, F., \& Arifin. (2015). Pengaruh Relationship Marketing (Pemasaran Relasional) terhadap Kepuasan Nasabah serta Dampaknya Pada Loyalitas Nasabah. Jurnal Administrasi Bisnis (JAB), 28(2).

Sheng, T., \& Liu, C. (2010). An empirical study on the effect of e-service quality on online customer satisfaction and loyalty. Nankai Business Review International, 1(3), 273-283. https://doi.org/10.1108/20408741011069205

Suhartanto, D., Dean, D., Sarah, I. S., Hapsari, R., Amalia, F. A., \& Suhaeni, T. (2020). Does religiosity matter for customer loyalty? Evidence from halal cosmetics. Journal of Islamic Marketing. https://doi.org/10.1108/JIMA-03-2020-0069

Sulistiyorini, U. T. (2018). Metode Penelitian: Kausal-Regresi. Penerbit Polines.

Tjiptono, F. (2007). Pemasaran Jasa. ANDI.

Tjokro, C. I., Bisnis, J. A., \& Ambon, P. N. (2018). Determinan Kepuasan Nasabah dalam Membentuk Loyalitas Nasabah. Jurnal Manajemen, Ide, Inspirasi (MINDS), 5(1), 1-19.

Zaini, H., Rozzaid, Y., \& Qomariah, N. (2017). Impact Relationship Marketing, Trust, and Customer Values to Customer Satisfaction. Jurnal Sains Manajemen Dan Bisnis Indonesia, 7(1), 77-96.

Zhang, D., Hu, M., \& Ji, Q. (2020). Financial markets under the global pandemic of COVID-19. Finance Research Letters, March, 101528. https://doi.org/10.1016/j.frl.2020.101528.

bi.go.id. Laporan Keuangan dan Ekonomi Syariah. Jakarta. Https://www.bi.go.id: Bank Indonesia, 2019.

Covid19.go.id. Data Sebaran . Mei 16, 2020. http://www.covid19.go.ig (accessed Mei 17, 2020).

ojk.go.id. Siaran Pers Bulan Mei Stabilitas Sektor Jasa Keuangan Tetap Terjaga Di Tengah Pandemi Covid-19. Jakarta. https://www.ojk.go.id: Otoritas Jasa Keuangan, Mei 2020. 